\title{
On the Application of the Idea of Human Centered Education in the Political Education of College Students
}

\author{
Wei JIAO \\ Shandong Technology and Business University \\ Yantai, Shandong, 264005
}

\begin{abstract}
This paper analyzed the ideological and political education of college students from the perspective of humanistic thought, and probed into the problems and challenges in the application of humanistic thought to college students ' ideological and political education. of the key point of this paper is how to apply humanistic education thought to college students ' ideological and political education which was illustrated from four aspects, such as education subject, educational object, educational medium and education environment. However, these four dimensions are not irrelevant but complement each other and form an system. This paper attempted to explore the application of humanistic thought in college students ' ideological and political education by means of literature research, theoretical research, comparative analysis and inductive synthesis.
\end{abstract}

Keywords-Human-oriented education; College students' ideological and political education

I. THE NECESSITY OF APPLYING HUMANISTIC EDUCATION IN COLLEGE STUDENTS ' IDEOLOGICAL AND POLITICAL EDUCATION

\section{A. Meet the needs of the progress of the Times and social development}

The current social development is changing rapidly, and the economic and social transformation are accelerated. Under such circumstances, it is very necessary for us to apply humanistic education to the ideological and political education of contemporary college students. As society and economy progresses, it is urgent for education at all levels, especially university education to cultivate talents with independent personality and creative thinking. Humanistic education thought is the extension and evolvement of Marx's theory of human science, which satisfies the realistic need of social economic development and reform. Social progress brings the subject personality and independent personality. Whereas, it is easy to generate one-sided or abnormal development tendency. However, the humanistic education thought can promote the comprehensive development of students. The rapid development of information technology shortens the distance between people, and also changes the communication between teachers and students. At the same time, the diversified value orientation also begins to penetrate into the life and thought of college students. Then, it is necessary for us to integrate humanistic education into the ideological and political education of contemporary college students, and actively guide them to set up correct values and subjective concept, so as to better promote college students to adapt to the current social informatization trend.

\section{B. The need of improving college students 'ideological and moral quality}

College students' ideological and political education is an important way to promote college students ' ideological and moral quality. Therefore, the application of humanistic education to higher ideological and political education system is of great significance to promote the improvement of college students ' ideological and moral quality. On the one hand, humanistic education is an important idea of college students ' ideological and moral education. The formation and development of ideological and moral quality are complementary to the ideological and political education of college students. On the other hand, to achieve the externalization of the ideology and morality of students, we need to arouse their emotion and will, transform the students ' inner knowledge and feeling, thought and acts, and then form a certain ideological and moral character. [1] Therefore, in the ideological and political education of college students, we should combine the norms and values of humanistic education to fully consider the needs of college students ' realistic ideological and moral quality, so that they can fully and freely exert their own initiative, further realizes the transformation between the knowledge and the action, strengthens the moral quality construction level.

\section{The need of improving the actual effect of ideological and political education}

The aim of college students ' ideological and political education is to promote people's ideological and political level as well as the all-round improvement of moral quality. So, from the perspective of cultivating people comprehensively, the humanistic education thought is urgent and necessary to reform the traditional education mode, innovate the idea of ideological and political education and enhance the actual effect of the education. The humanistic education thought attaches importance to the students ' subject status, respects the students ' individual will and satisfies the personality development of the people. Under the guidance of humanistic education, educators can give more attention and care to 
students, so that they can grasp the characteristics of students, understand the needs of students, carry out targeted teaching activities, fully inspire the initiative of college students and their enthusiasm, fundamentally, promote the ideological and political education work to achieve good results. [2]

\section{PROBLEMS IN THE APPLICATION OF HUMANISTIC EDUCATION IN COLLEGE STUDENTS 'IDEOLOGICAL AND POLITICAL EDUCATION}

\section{A. Poor identification of educational objectives}

For a period of time, our ideological and political education is based on the special historical background and social environment, so this work is often regarded as a political education which neglects college students inherent spiritual pursuit. Thus, to win the recognition of the goal of education by students is a relatively difficult task. [3]

\section{B. The educational process is divorced from reality}

The teaching activities of college students ' ideological and political theory course will be different according to the actual situation of various colleges and universities. In addition to classroom education, there will be such auxiliary forms as ideological lectures and ideological content competitions. However, no matter how the teaching forms changes, the actual effect of teaching is not better than before. Our research found that the root of the problem lies in the ideological and political education in which the teaching process is separate from the actual situation. That restricts the realization of the educational effect and the attainment of the educational goal, and then affects the practical embodiment of the humanistic education idea. [4]

\section{Lack of protection of educational resources}

With the social progress, as well as the gradual enlargement of enrollment scale, especially after the joining of the students born after 1995, the ideological and political education resources in colleges and universities are far from enough in the course of completing the task. And the teachers in the ideological and political courses shoulder more responsibility for teaching tasks, and the teaching and scientific research is insufficient, which makes it difficult to follow the national development. The lack of humanistic education resources is also reflected in the shortage of teaching facilities, the process of educational practice, and many other aspects. The existence of a series of problems seriously restricts the implementation of humanistic education, and affects the development of college students 'ideological and political education. [5]

\section{Low effectiveness of educational methods}

The teaching method of college students 'ideological and political education is very important to implement humanistic education thought. At present, the teaching methods and means of ideological and political education in universities lag behind, and there are still a series of problems and deficiencies in the practical application. The existing education methods, lack of effective standard and institutionalized mode of operation, results in lower teaching effectiveness. Most educators are familiar with the theory of various teaching methods, but short of operable guidance to realize this teaching method. [6] It is because of these problems that some of the original effective teaching methods can only stay in the theoretical sense. Moreover, the traditional methods of ideological and political education of college students embody the problem of peopleoriented, which greatly reduces the acceptability of students.

\section{THE CAUSES OF THE PROBLEMS IN THE APPLICATION OF HUMANISTIC EDUCATION IN THE IDEOLOGICAL AND POLITICAL EDUCATION OF COLLEGE STUDENTS}

\section{A. The conflict between diversified culture and values in the period of social transformation}

From the macro-economic social background of our country, the social transformation, the prosperity of the economy and the foreign culture infiltration and the development of the information media have aggravated the conflict between the diversified culture and the values of our country. Various forms of mainstream culture and non-mainstream culture, local culture and foreign culture, traditional culture and modern culture grow at the same time. The diversification of value culture leads to the dispute of value culture. In addition, with the deepening of economic globalization, the depth and breadth of communication between China and the West continue to improve, which to a large extent, helps the ideology of the western hostile forces sneak into the study and life of college students.

\section{B. The disconnect between educational subject and educational object in traditional concept}

In college students 'ideological and political education, the interaction and communication between the subject and the object of education are very important. The object of ideological and political education is the person who exists in reality and is the object with special status. The interaction between the subject and object of ideological and political education of college students, in essence, is the relationship between the educator and the educated, which is the unification of the process of education and the process of being educated. Educators should first accept education to become the subject of education, and in the process of education, accept the choice and evaluation of the educated. [7] At the same time, as the educated, dose not simply accept negatively, but also choose comprehend and recognize.

\section{THE APPLICATION OF HUMANISTIC EDUCATION IN IDEOLOGICAL AND POLITICAL EDUCATION OF COLLEGE STUDENTS}

\section{A. The application of humanistic education in the subject of education}

To realize the role change of the subject of education, the educational subject plays a vital role in the ideological and political education and the important part of the application of education is the change of the role of education subject. In the process of education, ideological and political educators should make clear their role as the implementing person of humanistic education, which is the intrinsic demand of carrying out ideological and political education with humanistic thought. 
The idea of innovative education subject reflects the respect of educators for the status of the educated in the process of education, as educators need to update and innovate the original relative backward thinking, so as to adapt to the new change of learning situation.

\section{B. The application of humanistic education in the object of education}

The ideological and political education work of college students under the guidance of humanistic education will promote the all-round development of students as the fundamental educational goal. Fully tap the inherent potential of all aspects of college students, so that students get free and all-round development, become rational and have a sense of the subject of personality. [8]

\section{The application of humanistic education thought in the educational media}

Enriching the content of ideological and political education of college students, ideological and political education in colleges and universities is an important way to cultivate college students ' outlook on life and values. In the three-view education, values sit at its core. The ideological and political workers in universities should complete the cultivation of the good values of college students with the humanistic educational ideas. [9]

Teaching method innovation is very important to promote the innovation of the mode of ideological and political education of college students. Any ideological and political thought can be put into practice by a set of effective educational methods. We should spark students' creativity, initiative and enthusiasm, and constantly enhance their ideological awareness and moral awareness, and promote the improvement of college students ' moral and humanistic quality. [10]

\section{Creating a good humanistic education environment}

To create the management atmosphere of humanistic education, we need to create the educational environment for humanistic education. It is necessary to focus on the practical effect and make full use of the existing educational resources on the basis of planning, targeted and purposeful optimization of the management atmosphere, and not lose touch with the actual situation. On the premise of insisting on the truth and stressing the effect, integrate the management idea of humanistic education into the management work.

\section{Conclusion}

China's higher education must form a new understanding and emphasis of its own ideological and political education work. That is to introduce and apply the idea of humanism to the ideological and political education of college students, and carry out the education principle of "people-oriented", centering on college students. We should examine the innovation and reform of college students 'ideological and political education in a more expansive and long-term perspective, which is the trend of realizing the regularization, scientific and humane development of college students' ideological and political education. Therefore, the application of humanistic education in the ideological and political education of college students is the enrichment and development of Marx's theory of human thought. The application of humanistic thought and idea in college students' ideological and political education is an intrinsic demand to promote the ideological and political education in contemporary universities. The application of humanistic education in college students ' ideological and political education provides a new way and prospect for us to carry out the development of all-round education in colleges and universities. Admittedly, in the actual work of college students ' ideological and political education, there still exist problems and drawbacks in the aspects of educational mode, teaching idea and teaching content. The idea of humanistic education is an effective tool to deal with these problems and drawbacks, which provides a practical way for us to change the backward education thought, renew the teaching mode and improve the college students ' ideological and political education.

\section{REFERENCES}

[1] Han Dan. The Transition Research of Ideological and Political Education Policies of Chinese Undergraduates [D]. Wuhan: Huazhong University of Science and Technology. 2012:21

[2] Wang Yang. The Service and Study Research of Universities' Ideological and Political Education [D]. Beijing: Beijing Jiaotong University. 2012:32

[3] Theories about the Construction of Communist Party of China. Beijing. Central Party Literature Press [M]. 2001.

[4] Xing Delu. The Exercises of Anthropic principles in HSR of Construction Firm [J]. 2015:424

[5] Zhang Ruimin, Niu Yufeng. Confucius' Anthropic Education Thoughts and Its Present Values [J]. Journal of Harbin University Newspaper. 2015: 29

[6] Wu Hengzhong. Scientific Contents of people-oriented Concern of Undergraduates Education Management [J]. Heilongjiang Researches on Higher Education. 2012(2)

[7] Huang Wenyan. The Exploration and Analysis to the Humanization of Ideological and Political Education of Universities [J]. Data of Culture and Education. 2009(29)

[8] Li Hongge, Wang Weifeng. The Exploration to the Humanization of Ideological and Political Education of Undergraduates. Journal of Hunan University of Science of Technology [J]. 2013(4)

[9] Tao Li. The Research of Undergraduates' Growth Trails from the View of Ideological and Political Education [D]. Liaoning: Liaoning University. 2010.28

[10] Yang Hongze. The Time-limited Research of Ideological and Political Education of Present Undergraduates [D]. Changchun: Northeast Normal University. 2013.43 